\title{
Metode K-Means Untuk Pemetaan Persebaran Usaha Mikro Kecil Dan Menengah
}

\author{
Dicky Jordan Aji Putra'); Dwi Remawati' ${ }^{2)}$; Tri Irawati ${ }^{3)}$ \\ 1)Program Studi S1 Informatika, STMIK Sinar Nusantara; \\ 2)Program Studi D3 Teknologi Informasi , STMIK Sinar Nusantara \\ 3)Program Studi D3 Sistem Informasi Akuntansi, STMIK Sinar Nusantara

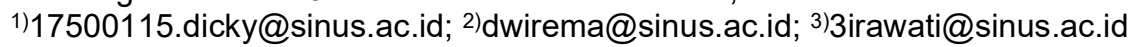

\begin{abstract}
Developments in the current era of globalization are very dependent on the economic sector which is the benchmark of success carried out by the government. The role of the community in national development in the economic field is the existence of Micro, Small and Medium Enterprises (MSMEs). To increase the role of MSMEs as a benchmark for the success of the economic sector, there must be support from the government, such as assistance for business owners with limited costs. The purpose of this study is to determine community business groups as a measure of the level of business, making it easier for the government to provide assistance. The K-Means Clustering method is a method used for grouping business levels based on the income that exists in today's society. The result of this research is a website-based business-level grouping system used by the Cooperatives and SMEs Office by grouping them into micro, small and medium-sized businesses based on income/assets.
\end{abstract}

Keywords : K-Means Clustering, MSMEs, Mapping

\section{PENDAHULUAN}

Beragam informasi sekarang dapat diperoleh dengan cepat, mudah, dan efektif. Berkembangnya teknologi mempengaruhi beragam media informasi. Banyaknya sistem informasi yang dapat digunakan dalam menunjang dan menyelesaikan suatu permasalahan yang biasanya timbul dalam suatu organisasi, perusahaan ataupun instansi pemerintahan.

Kecamatan Karangmalang memiliki luas wilayah yaitu 4.297,82 Ha, terdiri dari 8 Desa dan 2 Kelurahan. Tidak sedikit masyarakat Karangmalang yang bergerak dibidang peternakan, wiraswasta dan sebagian bergerak di bidang bahan primer kebutuhan sehari-hari. Karakteristik utama UMKM yaitu dapat mengembangkan proses bisnis yang fleksibel dengan menanggung biaya yang relatif rendah. Dengan menggunakan metode K-means tingkatan usaha akan dibagi menjadi 3 klaster yaitu mikro, kecil, dan menengah. K-means merupakan metode pengelompokan data nonhierarki (sekatan) yang dapat mempartisi sebuah data dalam bentuk dua kelompok atau lebih. Metode ini akan mempartisi data ke dalam suatu kelompok dimana data yang memiliki kesamaan akan dimasukkan dalam satu kelompok yang sama [1].

Pada penelitian ini akan dibuat sistem klasterisasi dan pemetaan UMKM yang diharapkan dapat meringankan kegiatan Dinas
Koperasi dan UKM dalam mengelompokan data UMKM yang akan digunakan dalam pendataan maupun mengelompokan penyaluran bantuan pelaku UMKM mikro.

\section{TINJAUAN PUSTAKA}

\subsection{Metode K-Means}

Algoritma K-Means merupakan suatu algoritma klasterisasi yang mengelompokkan suatu data berdasarkan titik pusat klaster (centroid) terdekat dengan data. Cluster merupakan sekelompok atau sekumpulan objek data yang similar satu sama lain dalam cluster yang sama. Objek akan dikelompokkan ke dalam satu atau lebih cluster sehingga objek yang berada dalam satu cluster akan mempunyai kesamaan yang tinggi antara objek satu dengan yang lainnya. Tujuan dari K-Means adalah pengelompokkan data dengan cara memaksimalkan kemiripan data dalam satu klaster dan meminimalkan kemiripan data antar klaster. Sebelum melakukan perhitungan data yang akan diolah harus disetarakan terlebih dahulu dengan rumus sebagai berikut :[2]

Nilai Normalisasi $=((($ data - data $\min ) *($ newmax - newmin) / (data max data $\min ()+$ newmin)

Clustering menggunakan metode K-Means secara umum dilakukan dengan algoritma sebagai berikut [3] : 
1. Menentukan $\mathrm{k}$ sebagai jumlah cluster yang akan dibentuk.

2. Membangkitkan nilai random untuk pusat cluster awal (centroid) sebanyak k.

3. Menghitung jarak data input terhadap setiap centroid menggunakan rumus jarak. Untuk menghitung jarak setiap centroid menggunakan rumus Euclidean (Euclidean Distance) yaitu:

$d(x i, \mu)=\sqrt{\sum(x i-\mu j)^{2}}$

Dimana:

$\mathrm{Xi}=$ data kriteria

$\mu j=$ centroid pada cluster $\mathrm{ke}-\mathrm{j}$

4. Mengelompokan setiap data berdasarkan kedekatannya dengan centroid jarak terkecil.

5. Memperbaharui nilai centroid baru. Nilai centroid baru diperoleh dari rata-rata cluster yang bersangkutan dengan menggunakan rumus:

$\mu j(t+1)=\frac{1}{N s j} \sum_{j \in S j} x j$

Dimana:

$\mu j(t+1)=$ centroid baru pada iterasi ke $(\mathrm{t}+1)$

$\mathrm{N} s j$ = banyak data pada cluster Sj.

6. Lakukan perulangan dari langkah 2 hingga

5 , sampai anggota cluster tidak ada yang berubah.

Jika langkah 6 terpenuhi, maka nilai pusat cluster $(\mu j)$ pada iterasi terakhir akan digunakan sebagai parameter untuk menentukan pengelompokan data. Algoritma k-means dapat digambarkan dalam bentuk flowchart seperti Gambar 1.

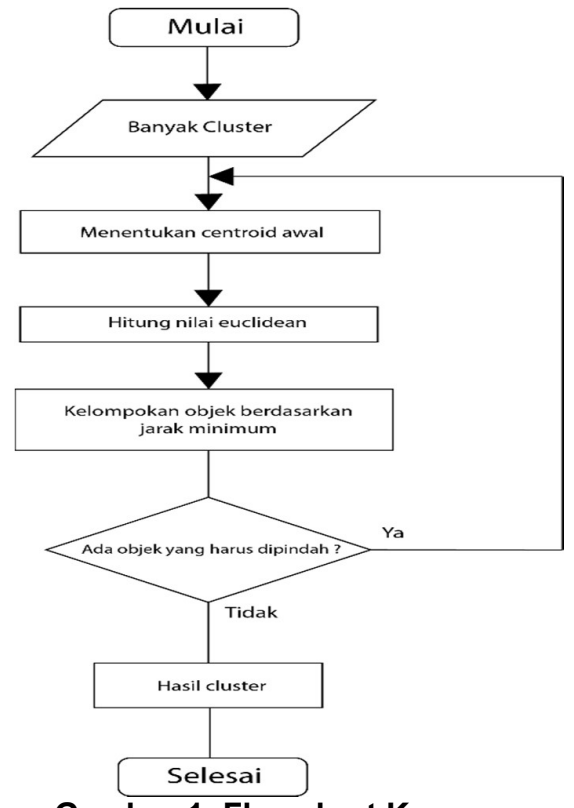

Gambar 1. Flowchart K-means

\subsection{Penelitian terdahulu}

Berikut adalah sumber-sumber penelitian terdahulu yang terkait pengelompokan data menggunakan metode k-means clustering.

Pengelompokan Minat Baca Mahasiswa Menggunakan Metode K-Means [4]. Dalam penelitian ini membahas tentang kurangnya minat baca dikarenakan pihak perpustakaan menjadikan statistik peminjaman buku terlaris sebagai acuan dalam peningkatan jumlah koleksi buku yang telah ada, tanpa mempertimbangkan buku mana yang menjadi prioritas utama untuk ditingkatkan koleksinya.

Selanjutnya penelitian tentang Penerapan Algoritma K-Means Clustering Untuk Prediksi Prestasi Nilai Akademik Mahasiswa [5]. Dalam penelitian ini meningkatnya jumlah mahasiswa baru tidak menutup kemungkinan bahwa mahasiswa lama akan lulus tepat waktu sehingga mengakibatkan jumlah mahasiswa semakin banyak banyak. Metode k-means dapat mengelompokan mahasiswa berdasarkan IPK dengan variabel yang digunakan yaitu nilai dari setiap mata kuliah.

Selanjutnya penelitian tentang Teknologi Geolocation Berbasis Android dengan Metode K-Means untuk Pemetaan UMKM di Kabupaten Jepara [6]. Dalam penelitian ini perkembangan teknologi berbasis mobile lebih disukai dan dapat memenuhi kebutuhan informasi yang cepat sehingga mempermudah wisatawan dalam pencarian sentra industri yang dituju dikarenakan banyaknya sentra industri kerajinan yang ada. Dengan menggunakan metode k-means akan dikelompokan industry dalam tiga klaster yaitu mikro, kecil, dan menengah.

Selanjutnya penelitian tentang Analisis Persebaran UMKM Kota Malang Menggunakan Cluster K-means [7]. Dalam penelitian ini UMKM Kota Malang memiliki potensi penyerapan tenaga kerja yang tinggi, tetapi masih terdapat permasalahan yaitu sulitnya mendapatkan modal, keterbatasan sumber daya manusia dan terbatasnya akses informasi peluang pasar.

Selanjutnya penelitian tentang Penerapan Clustering K-Means Untuk Menentukan Pengaruh Media Sosial Facebook Terhadap Usaha Mikro, Kecil, dan Menengah [8]. Dalam penelitia ini metode k-means digunakan untuk menentukan pengaruh facebook terhadap UMKM di Pekanbaru dengan menggunakan beberapa variabel dan metode kuantitatif berupa kuisioner, hasil kuisioner akan diolah dengan menggunakan metode k-means. 


\section{METODE PENELITIAN}

Perancangan sistem

pengelompokan UMKM

aplikasi

Karangmalang ini dilakukan dengan metode Waterfall, metode pengumpulan data dan perancangan sistem.

\subsection{Metode Pengumpulan Data}

Pada tahap ini digunakan untuk mendapatkan informasi yang akurat. Penulis menggunakan data primer yang diperoleh dari Dinas Koperasi dan UKM Kabupaten Sragen dan data sekunder yang diperoleh dari buku, jurnal maupun internet. Sumber data primer dan sekunder diperoleh dengan cara observasi, wawancara, dan studi pustaka.

\subsection{Langkah Penelitian}

Langkah pada penelitian ini dengan menggunakan tahap analisa data, tahap desain (system design), tahap implementasi sistem, tahap pengujian sistem.

1. Tahap analisa data

Pada tahap analisis data dilakukan dengan metode k-means clustering, dimana data akan dikelompokan ke dalam tiga kelompok yaitu mikro, kecil, dan menengah. Hasil pengelompokan data tersebut akan dipetakan dengan menggunakan titik koordinat yang telah didapat dari google maps.

2. Tahap analisa kebutuhan sistem

Tahap analisa kebutuhan sistem ini meliputi perangkat keras (hardware) dan perangkat lunak (software). Tahap ini digunakan untuk memenuhi kebutuhan dalam pembuatan sistem serta kebutuhan lainnya.

3. Tahap perancangan sistem

Tahap ini merupakan suatu fase dimana diperlukan sebuah keahlian untuk elemenelemen komputer yang akan menggunakan sistem baru dengan memberikan gambaran tentang apa yang akan dikerjakan dan bagaimana hasil yang akan ditampilkan. Membuat desain sistem memerlukan beberapa tahapan yaitu diagram konteks, HIPO, DAD, desain database, desain input dan output.

4. Tahap implementasi sistem

Pada tahap implementasi dilakukan penggambaran program sesuai dengan analisa dan perancangan sistem. Disusun dan dirancang dengan menggunakan metode $K$ Means Clustering dalam proses pemetaan data UMKM kemudian akan dilakukan penerapan Geographic Information System (GIS).

\section{Tahap pengujian sistem}

Tahap pengujian sistem aplikasi menggunakan dua pengujian yaitu pengujian fungsional dengan Black Box untuk menguji alur sistem aplikasi apakah sudah sesuai atau masih ada kesalahan dan pengujian validasi dengan silhouette coefficient.

\section{HASIL DAN PEMBAHASAN \\ 4.1 Perhitungan K-Means}

Metode K-Means Clustering digunakan untuk mengelompokan data UMKM Kecamatan Karangmalang yang terbagi menjadi tiga cluster. Ada 40 data UMKM yang akan dihitung menggunakan metode k-means dapat dilihat pada Tabel 1.

\section{Tabel 1. Data UMKM}

\begin{tabular}{|c|c|c|c|c|}
\hline No & $\begin{array}{l}\text { Nama } \\
\text { Usaha }\end{array}$ & Omset & Aset & $\begin{array}{c}\text { Tenaga } \\
\text { Kerja }\end{array}$ \\
\hline 1 & Usaha 1 & 144.000 .000 & 50.000 .000 & 1 \\
\hline 2 & Usaha 2 & 120.000 .000 & 50.000 .000 & 1 \\
\hline 3 & Usaha 3 & 96.000 .000 & 20.000 .000 & 1 \\
\hline 4 & Usaha 4 & 120.000 .000 & 50.000 .000 & 1 \\
\hline 5 & Usaha 5 & 72.000 .000 & 5.000 .000 & 2 \\
\hline 6 & Usaha 6 & 2.400 .000 .000 & 100.000 .000 & 3 \\
\hline 7 & Usaha 7 & 48.000 .000 & 3.000 .000 & 2 \\
\hline 8 & Usaha 8 & 72.000 .000 & 5.000 .000 & 2 \\
\hline 9 & Usaha 9 & 31.200 .000 & 10.000 .000 & 1 \\
\hline 10 & Usaha 10 & 62.400 .000 & 50.000 .000 & 4 \\
\hline 11 & Usaha 11 & 62.400 .000 & 20.000 .000 & 3 \\
\hline 12 & Usaha 12 & 46.800 .000 & 15.000 .000 & 2 \\
\hline 13 & Usaha 13 & 109.200 .000 & 2.000 .000 & 1 \\
\hline 14 & Usaha 14 & 93.600 .000 & 2.000 .000 & 1 \\
\hline 15 & Usaha 15 & 109.200 .000 & 15.000 .000 & 1 \\
\hline 16 & Usaha 16 & 78.000 .000 & 1.000 .000 & 1 \\
\hline 17 & Usaha 17 & 81.600 .000 & 10.000 .000 & 1 \\
\hline 18 & Usaha 18 & 1.440 .000 .000 & 100.000 .000 & 4 \\
\hline 19 & Usaha 19 & 192.000 .000 & 25.000 .000 & 2 \\
\hline 20 & Usaha 20 & 192.000 .000 & 25.000 .000 & 2 \\
\hline 21 & Usaha 21 & 31.200 .000 & 3.000 .000 & 2 \\
\hline 22 & Usaha 22 & 31.200 .000 & 17.500 .000 & 2 \\
\hline 23 & Usaha 23 & 31.200 .000 & 1.000 .000 & 1 \\
\hline 24 & Usaha 24 & 31.200 .000 & 10.000 .000 & 2 \\
\hline 25 & Usaha 25 & 218.000 .000 & 3.000 .000 & 1 \\
\hline 26 & Usaha 26 & 156.000 .000 & 2.000 .000 & 1 \\
\hline 27 & Usaha 27 & 280.800 .000 & 10.000 .000 & 1 \\
\hline 28 & Usaha 28 & 218.400 .000 & 5.000 .000 & 2 \\
\hline 29 & Usaha 29 & 240.000 .000 & 30.000 .000 & 2 \\
\hline 30 & Usaha 30 & 240.000 .000 & 20.000 .000 & 1 \\
\hline 31 & Usaha 31 & 156.000 .000 & 25.000 .000 & 2 \\
\hline 32 & Usaha 32 & 2.400 .000 .000 & 600.000 .000 & 7 \\
\hline 33 & Usaha 33 & 720.000 .000 & 500.000 .000 & 2 \\
\hline 34 & Usaha 34 & 180.000 .000 & 200.000 .000 & 2 \\
\hline 35 & Usaha 35 & 120.000 .000 & 7.000 .000 & 2 \\
\hline 36 & Usaha 36 & 300.000 .000 & 20.000 .000 & 2 \\
\hline 37 & Usaha 37 & 60.000 .000 & 25.000 .000 & 2 \\
\hline 38 & Usaha 38 & 60.000 .000 & 30.000 .000 & 2 \\
\hline 39 & Usaha 39 & 36.000 .000 & 40.000 .000 & 2 \\
\hline 40 & Usaha 40 & 60.000 .000 & 25.000 .000 & 2 \\
\hline
\end{tabular}

Dari Tabel 1 data UMKM maka akan dilakukan normalisasi data yang bertujuan untuk menyetarakan nilai rupiah dari kriteriakriteria yang ada dengan skala antara 1 sampai 10 agar data dapat dihitung menggunakan metode K-Means Clustering. Metode normalisasi yang digunakan yaitu max-min dengan rumus excel seperti persamaan 1. 
Normalisasi data 1 omset

$(144,000,000-31,200,000) *(10-1) /$

$(31,200,000-2,400,000,000)+1)=1,43$

Normalisasi data 1 aset

$(50,000,000-31,200,000) *(10-1) /$

$(31,200,000-2,400,000,000)+1)=1,74$

Normalisasi data 1 tenaga kerja

$(1-31,200,000) *(10-1) /(31,200,000-$

$2,400,000,000)+1)=1$

Adapun hasil dari normalisasi data dapat dilihat pada Tabel 2.

\section{Tabel 2. Normalisasi Data}

\begin{tabular}{|c|c|c|c|c|}
\hline \multicolumn{5}{|c|}{ Normalisasi Data } \\
\hline No & Nama Usaha & Omset & Aset & Tenaga Kerja \\
\hline 1 & Usaha 1 & 1,43 & 1,74 & 1 \\
\hline 2 & Usaha 2 & 1,34 & 1,74 & 1 \\
\hline 3 & Usaha 3 & 1,25 & 1,29 & 1 \\
\hline 4 & Usaha 4 & 1,34 & 1,74 & 1 \\
\hline 5 & Usaha 5 & 1,16 & 1,06 & 2,5 \\
\hline 6 & Usaha 6 & 10 & 2,49 & 4,00 \\
\hline 7 & Usaha 7 & 1,06 & 1,03 & 2,50 \\
\hline 8 & Usaha 8 & 1,16 & 1,03 & 2,50 \\
\hline 9 & Usaha 9 & 1 & 1,14 & 1 \\
\hline 10 & Usaha 10 & 1,12 & 1,74 & 5,50 \\
\hline 11 & Usaha 11 & 1,12 & 1,29 & 4,00 \\
\hline 12 & Usaha 12 & 1,06 & 1,21 & 2,50 \\
\hline 13 & Usaha 13 & 1,30 & 1,02 & 1 \\
\hline 14 & Usaha 14 & 1,24 & 1,02 & 1 \\
\hline 15 & Usaha 15 & 1,30 & 1,21 & 1 \\
\hline 16 & Usaha 16 & 1,18 & 1 & 1 \\
\hline 17 & Usaha 17 & 1,19 & 1,14 & 1 \\
\hline 18 & Usaha 18 & 6,35 & 2,49 & 5,50 \\
\hline 19 & Usaha 19 & 1,61 & 1,36 & 2,50 \\
\hline 20 & Usaha 20 & 1,61 & 1,36 & 2,50 \\
\hline 21 & Usaha 21 & 1 & 1,03 & 2,50 \\
\hline 22 & Usaha 22 & 1 & 1,25 & 2,50 \\
\hline 23 & Usaha 23 & 1 & 1 & 1 \\
\hline 24 & Usaha 24 & 1 & 1,14 & 2,50 \\
\hline 25 & Usaha 25 & 1,71 & 1,03 & 1 \\
\hline 26 & Usaha 26 & 1,47 & 1,02 & 1,00 \\
\hline 27 & Usaha 27 & 1,95 & 1,14 & 1 \\
\hline 28 & Usaha 28 & 1,71 & 1,06 & 2,5 \\
\hline 29 & Usaha 29 & 1,79 & 1,44 & 2,50 \\
\hline 30 & Usaha 30 & 1,79 & 1,29 & 1 \\
\hline 31 & Usaha 31 & 1,47 & 1,36 & 2,50 \\
\hline 32 & Usaha 32 & 10 & 10 & 10 \\
\hline 33 & Usaha 33 & 3,62 & 8,50 & 2,50 \\
\hline 34 & Usaha 34 & 1,57 & 3,99 & 2,50 \\
\hline 35 & Usaha 35 & 1,34 & 1,09 & 2,50 \\
\hline 36 & Usaha 36 & 2,02 & 1,29 & 2,50 \\
\hline 37 & Usaha 37 & 1,11 & 1,36 & 2,50 \\
\hline 38 & Usaha 38 & 1,11 & 1,44 & 2,50 \\
\hline 39 & Usaha 39 & 1,02 & 1,59 & 2,50 \\
\hline 40 & Usaha 40 & 1,11 & 1,36 & 2,50 \\
\hline
\end{tabular}

Kemudian untuk proses clustering akan dilakukan dengan menggunakan data hasil normalisasi pada Tabel 2. Menentukan pusat cluster (centroid) awal untuk memulai proses perhitungan k-means yang diperoleh secara acak/random. Pada penelitian ini digunakan data ke 23 sebagai pusat cluster $\mathrm{C} 1$, data ke 18 sebapai pusat cluster C2, dan data ke 32 sebagai pusat cluster C3.

- Tentukan centroid awal secara acak

$\mathrm{C} 1=(1,1,1)$

$\mathrm{C} 2=(6.35,2.49,5.50)$

$\mathrm{C} 3=(10,10,10)$
- Menghitung jarak terpendek dengan rumus 1 Jarak pusat cluster 1

$$
\begin{gathered}
C 1=\sqrt{(1,43-1)^{2}+(1,74-1)^{2}+(1-1)^{2}} \\
=0,851882463
\end{gathered}
$$

Jarak pusat cluster 2

$$
\begin{gathered}
\mathrm{C} 2=\sqrt{(1,43-6,35)^{2}+(1,74-2,49)^{2}+(1-5,50)^{2}} \\
=6,711082837
\end{gathered}
$$

Jarak pusat cluster 3

$$
\begin{gathered}
C 3=\sqrt{(1,43-10)^{2}+(1,74-10)^{2}+(1-10)^{2}} \\
=14,92512416
\end{gathered}
$$

Hasil perhitungan di atas menghasilkan

\begin{tabular}{|c|c|c|c|c|c|}
\hline No & Nama & C1 & $\mathrm{C} 2$ & C3 & $\begin{array}{c}\text { Jarak } \\
\text { terdekat }\end{array}$ \\
\hline 1 & Usaha 1 & $\begin{array}{c}0,85188 \\
2463\end{array}$ & $\begin{array}{l}6,7110 \\
82837\end{array}$ & $\begin{array}{c}14,9251 \\
2416\end{array}$ & $\begin{array}{c}0,851882 \\
463\end{array}$ \\
\hline 2 & Usaha 2 & $\begin{array}{c}0,80985 \\
1583\end{array}$ & $\begin{array}{c}6,7782 \\
35213\end{array}$ & $\begin{array}{c}14,9776 \\
7754\end{array}$ & $\begin{array}{c}0,809851 \\
583\end{array}$ \\
\hline 3 & Usaha 3 & $\begin{array}{c}0,37697 \\
6349\end{array}$ & $\begin{array}{l}6,9101 \\
11924\end{array}$ & $\begin{array}{c}15,2830 \\
6042\end{array}$ & $\begin{array}{c}0,376976 \\
349\end{array}$ \\
\hline 4 & Usaha 4 & $\begin{array}{c}0,80985 \\
1583\end{array}$ & $\begin{array}{l}6,7782 \\
35213\end{array}$ & $\begin{array}{c}14,9776 \\
7754\end{array}$ & $\begin{array}{c}0,809851 \\
583\end{array}$ \\
\hline 5 & Usaha 5 & $\begin{array}{c}1,50918 \\
5788\end{array}$ & $\begin{array}{l}6,1670 \\
47967\end{array}$ & $\begin{array}{c}14,6425 \\
9421\end{array}$ & $\begin{array}{c}1,509185 \\
788\end{array}$ \\
\hline 6 & Usaha 6 & $\begin{array}{c}9,60273 \\
8889\end{array}$ & $\begin{array}{c}3,9462 \\
0151\end{array}$ & $\begin{array}{c}9,61446 \\
6693\end{array}$ & $\begin{array}{c}3,946201 \\
51\end{array}$ \\
\hline 7 & Usaha 7 & $\begin{array}{c}1,50165 \\
8167\end{array}$ & $\begin{array}{l}6,2510 \\
03862\end{array}$ & $\begin{array}{c}14,7161 \\
5234\end{array}$ & $\begin{array}{c}1,501658 \\
167\end{array}$ \\
\hline 8 & Usaha 8 & $\begin{array}{c}1,50828 \\
8009\end{array}$ & $\begin{array}{l}6,1740 \\
84617\end{array}$ & $\begin{array}{c}14,6609 \\
6033\end{array}$ & $\begin{array}{c}1,508288 \\
009\end{array}$ \\
\hline 9 & Usaha 9 & $\begin{array}{c}0,13522 \\
5376\end{array}$ & $\begin{array}{l}7,1209 \\
48973\end{array}$ & $\begin{array}{c}15,5107 \\
7784\end{array}$ & $\begin{array}{c}0,135225 \\
376\end{array}$ \\
\hline 10 & Usaha 10 & $\begin{array}{c}4,56136 \\
8461\end{array}$ & $\begin{array}{c}5,2854 \\
83572\end{array}$ & $\begin{array}{c}12,9390 \\
9799\end{array}$ & $\begin{array}{c}4,561368 \\
461\end{array}$ \\
\hline 11 & Usaha 11 & $\begin{array}{c}3,01588 \\
2691\end{array}$ & $\begin{array}{l}5,5739 \\
61023\end{array}$ & $\begin{array}{c}13,8138 \\
7873\end{array}$ & $\begin{array}{c}3,015882 \\
691 \\
\end{array}$ \\
\hline 12 & Usaha 12 & $\begin{array}{c}1,51583 \\
6522\end{array}$ & $\begin{array}{c}6,2152 \\
49077\end{array}$ & $\begin{array}{c}14,6097 \\
4266\end{array}$ & $\begin{array}{c}1,515836 \\
522\end{array}$ \\
\hline 13 & Usaha 13 & $\begin{array}{c}0,29673 \\
3223\end{array}$ & $\begin{array}{c}6,9256 \\
69884\end{array}$ & $\begin{array}{c}15,4104 \\
9166\end{array}$ & $\begin{array}{c}0,296733 \\
223\end{array}$ \\
\hline 14 & Usaha 14 & $\begin{array}{c}0,23755 \\
7695\end{array}$ & $\begin{array}{l}6,9690 \\
37302\end{array}$ & $\begin{array}{c}15,4440 \\
4434\end{array}$ & $\begin{array}{c}0,237557 \\
695\end{array}$ \\
\hline 15 & Usaha 15 & $\begin{array}{c}0,36341 \\
7421\end{array}$ & $\begin{array}{r}6,8867 \\
15824\end{array}$ & $\begin{array}{c}15,2974 \\
3165\end{array}$ & $\begin{array}{c}0,363417 \\
421\end{array}$ \\
\hline 16 & Usaha 16 & $\begin{array}{c}0,17781 \\
155\end{array}$ & $\begin{array}{c}7,0158 \\
13093\end{array}$ & $\begin{array}{c}15,4864 \\
7826\end{array}$ & $\begin{array}{c}0,177811 \\
55\end{array}$ \\
\hline 17 & Usaha 17 & $\begin{array}{c}0,23442 \\
2861\end{array}$ & $\begin{array}{c}6,9782 \\
26586\end{array}$ & $\begin{array}{c}15,4004 \\
5742\end{array}$ & $\begin{array}{c}0,234422 \\
861\end{array}$ \\
\hline 18 & Usaha 18 & $\begin{array}{c}7.14984 \\
2729\end{array}$ & 0 & $\begin{array}{c}9,03291 \\
7023\end{array}$ & 0 \\
\hline 19 & Usaha 19 & $\begin{array}{c}1,65930 \\
2117\end{array}$ & $\begin{array}{c}5,7213 \\
81867\end{array}$ & $\begin{array}{c}14,1868 \\
0743\end{array}$ & $\begin{array}{c}1,659302 \\
117\end{array}$ \\
\hline 20 & Usaha 20 & $\begin{array}{c}1,65930 \\
2117\end{array}$ & $\begin{array}{l}5,7213 \\
81867\end{array}$ & $\begin{array}{c}14,1868 \\
0743\end{array}$ & $\begin{array}{c}1,659302 \\
117\end{array}$ \\
\hline 21 & Usaha 21 & $\begin{array}{c}1,50030 \\
0972\end{array}$ & $\begin{array}{l}6,3050 \\
73652\end{array}$ & $\begin{array}{c}14,7549 \\
992\end{array}$ & $\begin{array}{c}1,500300 \\
972\end{array}$ \\
\hline 22 & Usaha 22 & $\begin{array}{c}1,52034 \\
8956\end{array}$ & $\begin{array}{c}6,2582 \\
1697\end{array}$ & $\begin{array}{c}14,6235 \\
7766\end{array}$ & $\begin{array}{c}1,520348 \\
956\end{array}$ \\
\hline
\end{tabular}
nilai cluster 1 yaitu 0,851882463 cluster 2 yaitu 6,711082837 dan cluster 3 yaitu 14,92512416. Hasil perhitungan di atas akan ditunjukkan pada Tabel 3.

Tabel 3. Hasil perhitungan iterasi ke 1 


\begin{tabular}{|c|c|c|c|c|c|}
\hline No & Nama & C1 & C2 & C3 & $\begin{array}{c}\text { Jarak } \\
\text { terdekat }\end{array}$ \\
\hline 23 & Usaha 23 & 0 & $\begin{array}{c}7,1479 \\
08785\end{array}$ & $\begin{array}{c}15,5884 \\
5727\end{array}$ & 0 \\
\hline 24 & Usaha 24 & $\begin{array}{c}1,50608 \\
2967\end{array}$ & $\begin{array}{l}6,2815 \\
53493\end{array}$ & $\begin{array}{c}14,6912 \\
9774\end{array}$ & $\begin{array}{c}1,506082 \\
967\end{array}$ \\
\hline 25 & Usaha 25 & $\begin{array}{c}0,71036 \\
2325\end{array}$ & $\begin{array}{l}6,6267 \\
33165\end{array}$ & $\begin{array}{c}15,1719 \\
688\end{array}$ & $\begin{array}{c}0,710362 \\
325\end{array}$ \\
\hline 26 & Usaha 26 & $\begin{array}{c}0,47440 \\
2126\end{array}$ & $\begin{array}{l}6,7970 \\
08645\end{array}$ & $\begin{array}{c}15,3107 \\
6916\end{array}$ & $\begin{array}{c}0,474402 \\
126\end{array}$ \\
\hline 27 & Usaha 27 & $\begin{array}{c}0,95792 \\
0876\end{array}$ & $\begin{array}{l}6,4389 \\
53977\end{array}$ & $\begin{array}{c}14,9804 \\
4214\end{array}$ & $\begin{array}{c}0,957920 \\
876\end{array}$ \\
\hline 28 & Usaha 28 & $\begin{array}{c}1,66116 \\
9223\end{array}$ & $\begin{array}{l}5,7063 \\
69279\end{array}$ & $\begin{array}{c}14,3134 \\
6389\end{array}$ & $\begin{array}{c}1,661169 \\
223\end{array}$ \\
\hline 29 & Usaha 29 & $\begin{array}{c}1,75191 \\
4084\end{array}$ & $\begin{array}{l}5,5565 \\
17705\end{array}$ & $\begin{array}{c}14,0337 \\
6271\end{array}$ & $\begin{array}{c}1,751914 \\
084\end{array}$ \\
\hline 30 & Usaha 30 & $\begin{array}{c}0,84311 \\
4497\end{array}$ & $\begin{array}{l}6,5164 \\
61796\end{array}$ & $\begin{array}{c}14,9764 \\
0286\end{array}$ & $\begin{array}{c}0,843114 \\
497\end{array}$ \\
\hline 31 & Usaha 31 & $\begin{array}{c}1,61395 \\
9327\end{array}$ & $\begin{array}{l}5,8351 \\
79302\end{array}$ & $\begin{array}{c}14,2681 \\
1453\end{array}$ & $\begin{array}{c}1,613959 \\
327\end{array}$ \\
\hline 32 & Usaha 32 & $\begin{array}{c}12,8160 \\
0562\end{array}$ & $\begin{array}{c}3,9462 \\
0151\end{array}$ & 0 & 0 \\
\hline 33 & Usaha 33 & $\begin{array}{c}8,08153 \\
7232\end{array}$ & $\begin{array}{l}7,2497 \\
70949\end{array}$ & $\begin{array}{c}9,96242 \\
6219\end{array}$ & $\begin{array}{c}7,249770 \\
949\end{array}$ \\
\hline 34 & Usaha 34 & $\begin{array}{c}3,39258 \\
3127\end{array}$ & $\begin{array}{l}5,8431 \\
86622\end{array}$ & $\begin{array}{c}12,7872 \\
4478\end{array}$ & $\begin{array}{c}3,392583 \\
127\end{array}$ \\
\hline 35 & Usaha 35 & $\begin{array}{c}1,54011 \\
5708\end{array}$ & $\begin{array}{l}6,0071 \\
52258\end{array}$ & $\begin{array}{c}14,5146 \\
9268\end{array}$ & $\begin{array}{c}1,540115 \\
708\end{array}$ \\
\hline 36 & Usaha 36 & $\begin{array}{c}1,83698 \\
1849\end{array}$ & $\begin{array}{l}5,4026 \\
59056\end{array}$ & $\begin{array}{c}13,9947 \\
4756\end{array}$ & $\begin{array}{c}1,836981 \\
849\end{array}$ \\
\hline 37 & Usaha 37 & $\begin{array}{c}1,54661 \\
1252\end{array}$ & $\begin{array}{l}6,1432 \\
23479\end{array}$ & $\begin{array}{c}14,4890 \\
1596\end{array}$ & $\begin{array}{c}1,546611 \\
252\end{array}$ \\
\hline 38 & Usaha 38 & $\begin{array}{c}1,56583 \\
2243\end{array}$ & $\begin{array}{l}6,1298 \\
56918\end{array}$ & $\begin{array}{c}14,4443 \\
4678\end{array}$ & $\begin{array}{c}1,565832 \\
243\end{array}$ \\
\hline 39 & Usaha 39 & $\begin{array}{c}1,61049 \\
719\end{array}$ & $\begin{array}{c}6,1842 \\
50486\end{array}$ & $\begin{array}{c}14,4124 \\
2014\end{array}$ & $\begin{array}{c}1,610497 \\
19\end{array}$ \\
\hline 40 & Usaha 40 & $\begin{array}{c}1,54661 \\
1252\end{array}$ & $\begin{array}{l}6,1432 \\
23479\end{array}$ & $\begin{array}{c}14,4890 \\
1596\end{array}$ & $\begin{array}{c}1,546611 \\
252\end{array}$ \\
\hline
\end{tabular}

Seletah mendapat hasil perhitungan dari iterasi pertama, hitung kembali titik pusat (centroid) untuk setiap cluster dengan menggunakan rumus persamaan (2). Berikut perhitungan menentukan centroid dari Tabel 3 dengan menggunakan persamaan 2 .

Cluster pertama (C1) iterasi2 memiliki 36 data:

$\mathrm{C} 1=\frac{\text { Jumlah nilai atribut cluster } 1}{\text { Jumlah data anggota cluster } 1}=\frac{47,64}{36}=1,322653$

$\mathrm{C} 1=\frac{\text { Jumlah nilai atribut cluster } 1}{\text { Jumlah data anggota cluster } 1}=\frac{47,92}{36}=1,331177$

$\mathrm{C} 1=\frac{\text { Jumlah nilai atribut cluster } 1}{\text { Jumlah data anggota cluster } 1}=\frac{72}{36}=2$

Cluster ke dua (C2) iterasi2 memiliki 3 data:

$\mathrm{C} 2=\frac{\text { Jumlah nilai atribut cluster } 2}{\text { Jumlah data anggota cluster } 2}=\frac{19,97}{3}=6,656535$

$\mathrm{C} 2=\frac{\text { Jumlah nilai atribut cluster } 2}{\text { Jumlah data anggota cluster } 2}=\frac{13.48}{3}=4,49$

$\mathrm{C} 2=\frac{\text { Jumlah nilai atribut cluster } 2}{\text { Jumlah data anggota cluster } 2}=\frac{12}{3}=4$

Cluster ke tiga (C3) iterasi2 memiliki 1 data:

$\mathrm{C} 3=\frac{\text { Jumlah nilai atribut cluster } 3}{\text { Jumlah data anggota cluster } 3}=\frac{10}{1}=10$

C3 $=\frac{\text { Jumlah nilai atribut cluster } 3}{\text { Jumlah data anggota cluster } 3}=\frac{10}{1}=10$

$\mathrm{C} 3=\frac{\text { Jumlah nilai atribut cluster } 3}{\text { Jumlah data anggota cluster } 3}=\frac{10}{1}=10$

Setelah mendapatkan centroid ke 2, ulangi perhitungan untuk menentukan nilai cluster setiap data pada iterasi ke 2 . Iterasi ke 2 ditunjukkan pada Tabel 4.

Tabel 4. Hasil perhitungan iterasi ke 2

\begin{tabular}{|c|c|c|c|c|c|}
\hline No & Nama & C1 & $\mathrm{C} 2$ & C3 & $\begin{array}{l}\text { Jarak } \\
\text { terdekat }\end{array}$ \\
\hline 1 & Usaha 1 & $\begin{array}{c}1,05356 \\
8074\end{array}$ & $\begin{array}{l}6,62716 \\
939\end{array}$ & $\begin{array}{l}14,925 \\
12416\end{array}$ & $\begin{array}{l}1,05356 \\
8074\end{array}$ \\
\hline 2 & Usaha 2 & $\begin{array}{c}1,06340 \\
544\end{array}$ & $\begin{array}{l}6,69933 \\
7049\end{array}$ & $\begin{array}{l}14,977 \\
67754\end{array}$ & $\begin{array}{l}1,06340 \\
544\end{array}$ \\
\hline 3 & Usaha 3 & $\begin{array}{c}1,03871 \\
3632\end{array}$ & $\begin{array}{l}6,96749 \\
1414\end{array}$ & $\begin{array}{l}15,283 \\
06042\end{array}$ & $\begin{array}{l}1,03871 \\
3632\end{array}$ \\
\hline 4 & Usaha 4 & $\begin{array}{c}1,06340 \\
544\end{array}$ & $\begin{array}{l}6,69933 \\
7049\end{array}$ & $\begin{array}{l}14,977 \\
67754\end{array}$ & $\begin{array}{l}1,06340 \\
544\end{array}$ \\
\hline 5 & Usaha 5 & $\begin{array}{c}0,70050 \\
912\end{array}$ & $\begin{array}{l}6,65481 \\
3648\end{array}$ & $\begin{array}{l}14,642 \\
59421\end{array}$ & $\begin{array}{l}0,70050 \\
912\end{array}$ \\
\hline 6 & Usaha 6 & $\begin{array}{c}8,80087 \\
1103\end{array}$ & $\begin{array}{l}3,89770 \\
7692\end{array}$ & $\begin{array}{l}9,6144 \\
66693\end{array}$ & $\begin{array}{l}3,89770 \\
7692\end{array}$ \\
\hline 7 & Usaha 7 & $\begin{array}{c}0,76384 \\
7521\end{array}$ & $\begin{array}{l}6,74575 \\
9102\end{array}$ & $\begin{array}{l}14,716 \\
15234\end{array}$ & $\begin{array}{l}0,76384 \\
7521\end{array}$ \\
\hline 8 & Usaha 8 & $\begin{array}{c}0,71606 \\
4885\end{array}$ & $\begin{array}{l}6,67035 \\
4894\end{array}$ & $\begin{array}{l}14,660 \\
96033\end{array}$ & $\begin{array}{l}0,71606 \\
4885\end{array}$ \\
\hline 9 & Usaha 9 & $\begin{array}{c}1,15049 \\
259\end{array}$ & $\begin{array}{l}7,22885 \\
8122\end{array}$ & $\begin{array}{l}15,510 \\
77784\end{array}$ & $\begin{array}{l}1,15049 \\
259\end{array}$ \\
\hline 10 & Usaha 10 & $\begin{array}{c}3,53534 \\
4507\end{array}$ & $\begin{array}{l}6,36452 \\
2619\end{array}$ & $\begin{array}{l}12,939 \\
09799\end{array}$ & $\begin{array}{l}3,53534 \\
4507\end{array}$ \\
\hline 11 & Usaha 11 & $\begin{array}{c}2,03943 \\
636\end{array}$ & $\begin{array}{l}6,39871 \\
8272\end{array}$ & $\begin{array}{l}13,813 \\
87873\end{array}$ & $\begin{array}{l}2,03943 \\
636\end{array}$ \\
\hline 12 & Usaha 12 & $\begin{array}{c}0,69448 \\
5523\end{array}$ & $\begin{array}{l}6,65889 \\
1488\end{array}$ & $\begin{array}{l}14,609 \\
74266\end{array}$ & $\begin{array}{l}0,69448 \\
5523\end{array}$ \\
\hline 13 & Usaha 13 & $\begin{array}{c}1,09439 \\
5452\end{array}$ & $\begin{array}{l}7,05781 \\
0705\end{array}$ & $\begin{array}{l}15,410 \\
49166\end{array}$ & $\begin{array}{l}1,09439 \\
5452\end{array}$ \\
\hline 14 & Usaha 14 & $\begin{array}{c}1,10680 \\
6075\end{array}$ & $\begin{array}{l}7,10292 \\
9431\end{array}$ & $\begin{array}{l}15,444 \\
04434\end{array}$ & $\begin{array}{l}1,10680 \\
6075\end{array}$ \\
\hline 15 & Usaha 15 & $\begin{array}{c}1,03965 \\
4307\end{array}$ & $\begin{array}{l}6,96369 \\
3109\end{array}$ & $\begin{array}{l}15,297 \\
43165\end{array}$ & $\begin{array}{l}1,03965 \\
4307\end{array}$ \\
\hline 16 & Usaha 16 & $\begin{array}{c}1,12761 \\
2817\end{array}$ & $\begin{array}{l}7,15557 \\
27\end{array}$ & $\begin{array}{l}15,486 \\
47826\end{array}$ & $\begin{array}{l}1,12761 \\
2817\end{array}$ \\
\hline 17 & Usaha 17 & $\begin{array}{c}1,08161 \\
6958\end{array}$ & $\begin{array}{l}7,08002 \\
298\end{array}$ & $\begin{array}{l}15,400 \\
45742\end{array}$ & $\begin{array}{l}1,08161 \\
6958\end{array}$ \\
\hline 18 & Usaha 18 & $\begin{array}{c}9,36377 \\
7316\end{array}$ & $\begin{array}{l}2,52106 \\
1914\end{array}$ & $\begin{array}{l}9,4863 \\
9111\end{array}$ & $\begin{array}{l}2,52106 \\
1914\end{array}$ \\
\hline 19 & Usaha 19 & $\begin{array}{c}0,51532 \\
2934\end{array}$ & $\begin{array}{l}6,12423 \\
5821\end{array}$ & $\begin{array}{l}14,186 \\
80743\end{array}$ & $\begin{array}{l}0,51532 \\
2934\end{array}$ \\
\hline 20 & Usaha 20 & $\begin{array}{c}0,51532 \\
2934\end{array}$ & $\begin{array}{l}6,12423 \\
5821\end{array}$ & $\begin{array}{l}14,186 \\
80743\end{array}$ & $\begin{array}{l}0,51532 \\
2934\end{array}$ \\
\hline 21 & Usaha 21 & $\begin{array}{c}0,80178 \\
3951\end{array}$ & $\begin{array}{l}6,79877 \\
213\end{array}$ & $\begin{array}{l}14,754 \\
9992\end{array}$ & $\begin{array}{l}0,80178 \\
3951\end{array}$ \\
\hline 22 & Usaha 22 & $\begin{array}{c}0,72388 \\
8677\end{array}$ & $\begin{array}{l}6,69050 \\
2186\end{array}$ & $\begin{array}{l}14,623 \\
57766\end{array}$ & $\begin{array}{l}0,72388 \\
8677\end{array}$ \\
\hline 23 & Usaha 23 & $\begin{array}{c}1,19025 \\
1827\end{array}$ & $\begin{array}{l}7,29261 \\
2578\end{array}$ & $\begin{array}{l}15,588 \\
45727\end{array}$ & $\begin{array}{l}1,19025 \\
1827\end{array}$ \\
\hline 24 & Usaha 24 & $\begin{array}{c}0,75738 \\
5766\end{array}$ & $\begin{array}{l}6,74584 \\
2405\end{array}$ & $\begin{array}{l}14,691 \\
29774\end{array}$ & $\begin{array}{l}0,75738 \\
5766\end{array}$ \\
\hline 25 & Usaha 25 & $\begin{array}{c}1,09126 \\
4183\end{array}$ & $\begin{array}{l}6,74150 \\
0517\end{array}$ & $\begin{array}{l}15,171 \\
9688\end{array}$ & $\begin{array}{l}1,09126 \\
4183\end{array}$ \\
\hline 26 & Usaha 26 & $\begin{array}{c}1,07605 \\
8773\end{array}$ & $\begin{array}{l}6,92373 \\
4846\end{array}$ & $\begin{array}{l}15,310 \\
76916\end{array}$ & $\begin{array}{l}1,07605 \\
8773\end{array}$ \\
\hline 27 & Usaha 27 & $\begin{array}{c}1,13136 \\
9085\end{array}$ & $\begin{array}{l}6,51361 \\
7449\end{array}$ & $\begin{array}{l}14,980 \\
44214\end{array}$ & $\begin{array}{l}1,13136 \\
9085\end{array}$ \\
\hline 28 & Usaha 28 & $\begin{array}{c}0,64766 \\
5036\end{array}$ & $\begin{array}{l}6,20287 \\
8841\end{array}$ & $\begin{array}{l}14,313 \\
46389\end{array}$ & $\begin{array}{l}0,64766 \\
5036\end{array}$ \\
\hline 29 & Usaha 29 & $\begin{array}{c}0,58161 \\
4745\end{array}$ & $\begin{array}{l}5,93586 \\
667\end{array}$ & $\begin{array}{l}14,033 \\
76271\end{array}$ & $\begin{array}{l}0,58161 \\
4745\end{array}$ \\
\hline 30 & Usaha 30 & $\begin{array}{c}1,05054 \\
2422\end{array}$ & $\begin{array}{l}6,55172 \\
8471\end{array}$ & $\begin{array}{l}14,976 \\
40286\end{array}$ & $\begin{array}{l}1,05054 \\
2422\end{array}$ \\
\hline 31 & Usaha 31 & $\begin{array}{c}0,50313 \\
3481\end{array}$ & $\begin{array}{l}6,23740 \\
5387\end{array}$ & $\begin{array}{l}14,268 \\
11453\end{array}$ & $\begin{array}{l}0,50313 \\
3481\end{array}$ \\
\hline 32 & Usaha 32 & $\begin{array}{c}12,0957 \\
2277\end{array}$ & $\begin{array}{l}8,80510 \\
3321\end{array}$ & 0 & 0 \\
\hline 33 & Usaha 33 & $\begin{array}{c}7,41295 \\
2866\end{array}$ & $\begin{array}{l}5,24805 \\
777\end{array}$ & $\begin{array}{l}9,9624 \\
26219\end{array}$ & $\begin{array}{l}5,24805 \\
777\end{array}$ \\
\hline
\end{tabular}




\begin{tabular}{|c|c|c|c|c|c|}
\hline No & Nama & C1 & C2 & C3 & $\begin{array}{c}\text { Jarak } \\
\text { terdekat }\end{array}$ \\
\hline 34 & Usaha 34 & $\begin{array}{c}2,62717 \\
5152\end{array}$ & $\begin{array}{l}5,33113 \\
5367\end{array}$ & $\begin{array}{l}12,787 \\
24478\end{array}$ & $\begin{array}{l}2,62717 \\
5152\end{array}$ \\
\hline 35 & Usaha 35 & $\begin{array}{c}0,61558 \\
3944\end{array}$ & $\begin{array}{l}6,48905 \\
9004\end{array}$ & $\begin{array}{l}14,514 \\
69268\end{array}$ & $\begin{array}{l}0,61558 \\
3944\end{array}$ \\
\hline 36 & Usaha 36 & $\begin{array}{c}0,73527 \\
2517\end{array}$ & $\begin{array}{l}5,83179 \\
5513\end{array}$ & $\begin{array}{l}13,994 \\
74756\end{array}$ & $\begin{array}{l}0,73527 \\
2517\end{array}$ \\
\hline 37 & Usaha 37 & $\begin{array}{c}0,63479 \\
3904\end{array}$ & $\begin{array}{l}6,54360 \\
1097\end{array}$ & $\begin{array}{l}14,489 \\
01596\end{array}$ & $\begin{array}{l}0,63479 \\
3904\end{array}$ \\
\hline 38 & Usaha 38 & $\begin{array}{c}0,63318 \\
6593\end{array}$ & $\begin{array}{l}6,50799 \\
8363\end{array}$ & $\begin{array}{l}14,444 \\
34678\end{array}$ & $\begin{array}{l}0,63318 \\
6593\end{array}$ \\
\hline 39 & Usaha 39 & $\begin{array}{c}0,71396 \\
1388\end{array}$ & $\begin{array}{l}6,51755 \\
3718\end{array}$ & $\begin{array}{l}14,412 \\
42014\end{array}$ & $\begin{array}{l}0,71396 \\
1388\end{array}$ \\
\hline 40 & Usaha 40 & $\begin{array}{c}0,63479 \\
3904\end{array}$ & $\begin{array}{l}6,54360 \\
1097\end{array}$ & $\begin{array}{l}14,489 \\
01596\end{array}$ & $\begin{array}{l}0,63479 \\
3904\end{array}$ \\
\hline
\end{tabular}

Hasil perhitungan yang diperoleh berhenti pada iterasi ke 2 dengan pusat cluster $\mathrm{C} 1$ : ( $1.322653,1.3311772$ ), pusat cluster C2 : ( $6.656535,4.49,4)$ dan pusat cluster C3 : (10, $10,10)$.

\subsection{Implementasi Sistem}

Implementasi sistem pada penelitian ini menggunakan sistem aplikasi berbasis web. Sistem yang dibangun menggunakan bahasa pemrograman PHP dan MySQL. Hasil dari implementasi program dapat dilihat seperti tampilan sebagai berikut :

1. Halaman user digunakan untuk pengguna aplikasi yang tidak memiliki username dan password. Dapat dilihat pada Gambar 2.

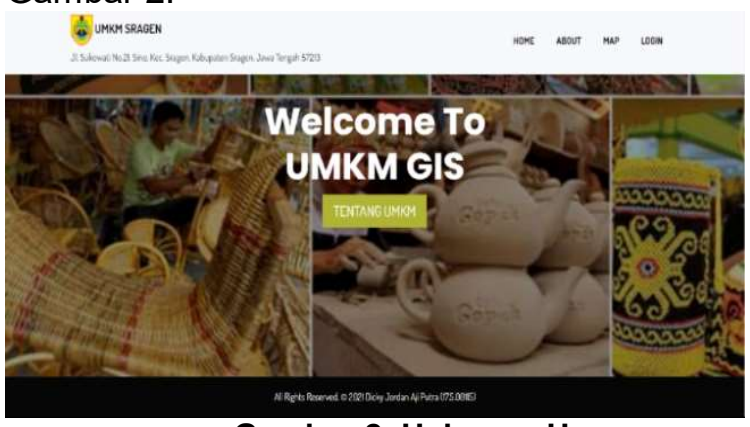

Gambar 2. Halaman User

2. Halaman admin digunakan oleh admin untuk mengelola aplikasi seperti memasukan data dan lain-lain. Dapat dilihat pada Gambar 3.

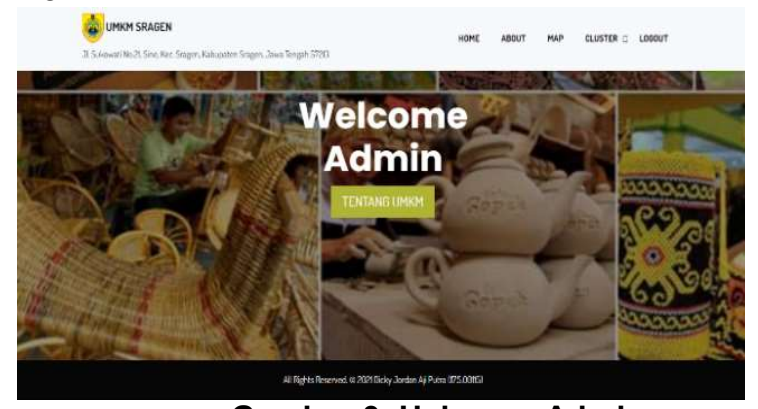

Gambar 3. Halaman Admin
3. Halaman about berisikan penjelasan tentang UMKM yang berada di Kecamatan Karangmalang dan kriteria dari UMKM. Dapat dilihat pada Gambar 4.

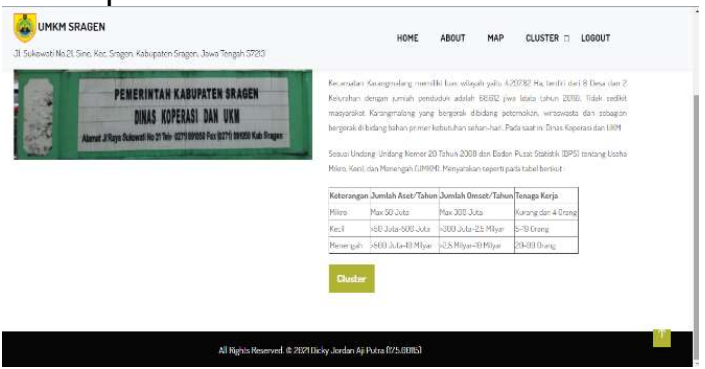

Gambar 4. Halaman About

4. Halaman centroid disini digunakan oleh admin untuk memasukan centroid baru untuk perhitungan algoritma k-means. Dapat dilihat pada Gambar 5.

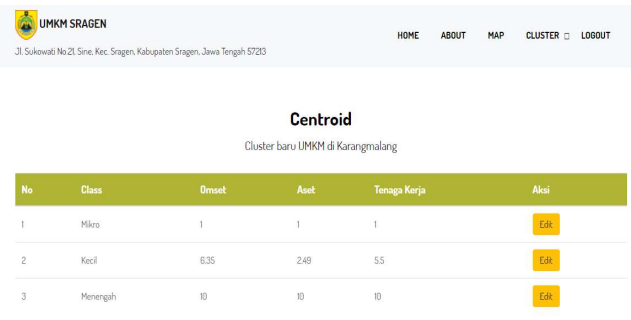

\section{Gambar 5. Halaman Centroid}

5. Halaman cluster digunakan oleh admin untuk memasukan data UMKM yang akan dihitung dengan algoritma k-means. Dapat dilihat pada Gambar 6.

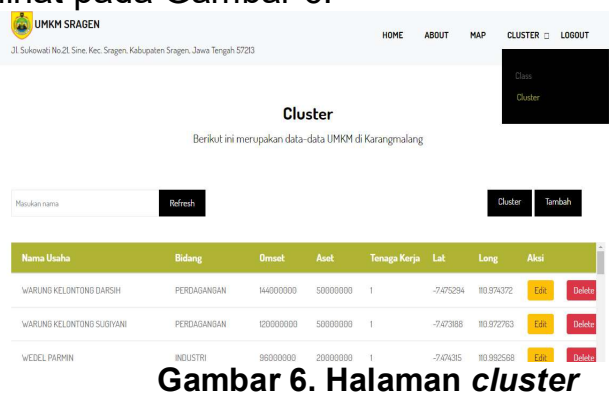

6. Halaman hasil clustering berisikan perhitungan dari algoritma k-means berupa pengelompokan data yang sudah selesai diolah. Dapat dilihat pada Gambar 7.

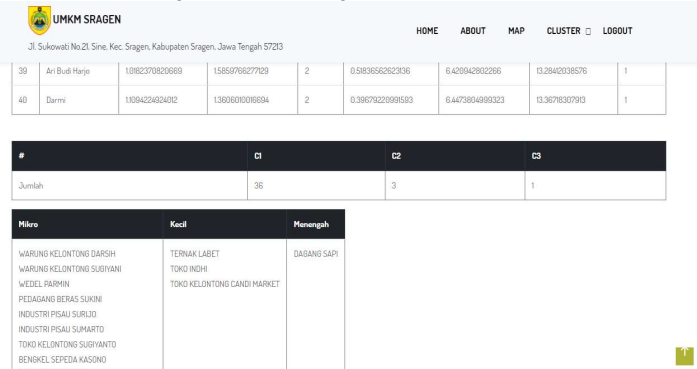

Gambar 7. Halaman Hasil Clustering 
7. Halaman map digunakan untuk menampilkan lokasi dari UMKM dan menampilkan tingkatan dari UMKM tersebut. Dari 200 data yang dimasukan ke dalam program, diperoleh 176 data UMKM termasuk mikro, 22 data UMKM termasuk kecil, dan 2 data UMKM termasuk menengah sesuai dengan peraturan UU No 20 Tahun 2008 tentang UMKM. Dapat dilihat pada Gambar 8.

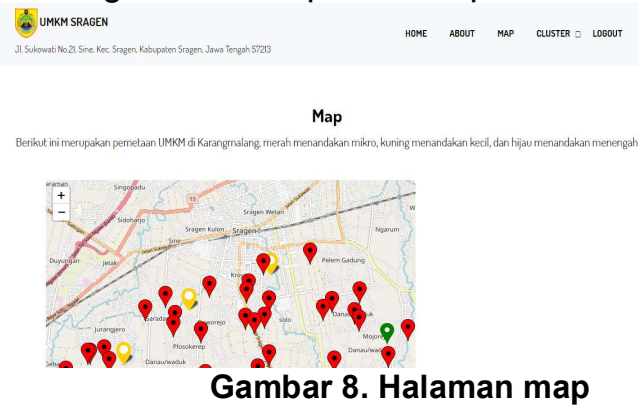

\subsection{Hasil Uji Sistem}

Sistem pengelompokan UMKM ini telah diuji dengan melakukan pengujian fungsional dan pengujian validasi. Pengujian ini dilakukan untuk menemukan kesalahan maupun kekurangan pada sistem. Pengujian fungsional dengan menggunakan Black Box dapat dilihat pada Tabel 5 .

Tabel 5. Uji Fungsional (Black Box)

\begin{tabular}{|c|c|c|c|c|}
\hline No & $\begin{array}{l}\text { Kompu } \\
\text { nen } \\
\text { sistem } \\
\text { yang } \\
\text { diuji } \\
\end{array}$ & Scenario uji & $\begin{array}{l}\text { Hasil yang } \\
\text { diharapkan }\end{array}$ & $\begin{array}{l}\text { Hasil } \\
\text { penguji } \\
\text { an }\end{array}$ \\
\hline \multirow[b]{2}{*}{1} & \multirow{2}{*}{$\begin{array}{l}\text { Halama } \\
\mathrm{n} \text { Login }\end{array}$} & $\begin{array}{l}\text { Masukan user dan } \\
\text { password dengan } \\
\text { benar }\end{array}$ & $\begin{array}{l}\text { Tampil masuk ke } \\
\text { menu home }\end{array}$ & Sesuai \\
\hline & & $\begin{array}{l}\text { Masukan user dan } \\
\text { password dengan } \\
\text { salah }\end{array}$ & $\begin{array}{l}\text { Muncul notif } \\
\text { kesalahan }\end{array}$ & Sesuai \\
\hline 2 & $\begin{array}{l}\text { Halama } \\
\text { n data } \\
\text { centroi } \\
\text { d }\end{array}$ & $\begin{array}{l}\text { Melakukan edit data } \\
\text { centroid yang ada }\end{array}$ & $\begin{array}{l}\text { Data berubah } \\
\text { berdasarkan } \\
\text { masukan baru }\end{array}$ & Sesuai \\
\hline \multirow{6}{*}{3} & \multirow{6}{*}{$\begin{array}{l}\text { Halama } \\
\text { n data } \\
\text { UMKM }\end{array}$} & $\begin{array}{l}\text { Menambahkan data } \\
\text { UMKM }\end{array}$ & $\begin{array}{l}\text { Tersimpan } \\
\text { dengan lengkap } \\
\text { di database }\end{array}$ & Sesuai \\
\hline & & $\begin{array}{l}\text { Kosongkan masukan } \\
\text { jumlah omset lalu } \\
\text { simpan }\end{array}$ & $\begin{array}{l}\text { Muncul pesan } \\
\text { "Silahkan isi } \\
\text { kolom ini" }\end{array}$ & Sesuai \\
\hline & & $\begin{array}{l}\text { Kosongkan masukan } \\
\text { jumlah aset lalu } \\
\text { simpan }\end{array}$ & $\begin{array}{l}\text { Muncul pesan } \\
\text { "Silahkan isi } \\
\text { kolom ini" }\end{array}$ & Sesuai \\
\hline & & $\begin{array}{l}\text { Kosongkan masukan } \\
\text { jumlah tenaga kerja } \\
\text { lalu simpan }\end{array}$ & $\begin{array}{l}\text { Muncul pesan } \\
\text { "Silahkan isi } \\
\text { kolom ini" }\end{array}$ & Sesuai \\
\hline & & $\begin{array}{l}\text { Melakukan edit data } \\
\text { UMKM }\end{array}$ & $\begin{array}{l}\text { Data berubah } \\
\text { berdasarkan } \\
\text { masukan baru }\end{array}$ & Sesuai \\
\hline & & $\begin{array}{l}\text { Melakukan hapus } \\
\text { data UMKM }\end{array}$ & $\begin{array}{l}\text { Data yang } \\
\text { terpilih telah } \\
\text { berhasil dihapus }\end{array}$ & Sesuai \\
\hline \multirow[t]{2}{*}{4} & \multirow{2}{*}{$\begin{array}{l}\text { Halama } \\
\mathrm{n} \text { hasil } \\
\text { clusteri } \\
\mathrm{ng}\end{array}$} & $\begin{array}{l}\text { Hasil yang akurat } \\
\text { dengan hasil } \\
\text { perhitungan manual } \\
\text { seimbang }\end{array}$ & $\begin{array}{l}\text { Terlihat hitungan } \\
\text { manual dan } \\
\text { program sesuai } \\
\text { dengan baik dan } \\
\text { akurat }\end{array}$ & Sesuai \\
\hline & & $\begin{array}{l}\text { Peta dapat } \\
\text { menampilkan lokasi } \\
\text { obyek }\end{array}$ & $\begin{array}{l}\text { Data obyek } \\
\text { dapat } \\
\text { ditampilkan }\end{array}$ & Sesuai \\
\hline
\end{tabular}

Berdasarkan hasil dari uji fungsional Black Box menunjukkan sistem yang telah dibuat tidak terdapat kesalahan dan menghasilkan hasil yang sesuai harapan. Kemudian dilakukan pengujian validasi dengan menggunakan Shilhoute Coeficient seperti pada Tabel 6.

Tabel 6. Uji Validasi (Shilhoute Coeficient)

\begin{tabular}{|c|c|c|c|c|c|}
\hline No & Nama & a (i) & b (i) & $\mathrm{s}(\mathrm{i})$ & $\begin{array}{c}\text { Keteranga } \\
n\end{array}$ \\
\hline 1 & Usaha 1 & $\begin{array}{c}1,3721 \\
4952\end{array}$ & $\begin{array}{c}9,6587 \\
043 \\
\end{array}$ & $\begin{array}{l}0.85722 \\
8653\end{array}$ & $\begin{array}{l}\text { Strong } \\
\text { Structure }\end{array}$ \\
\hline 2 & Usaha 2 & $\begin{array}{c}1,3657 \\
104\end{array}$ & $\begin{array}{c}9,7145 \\
029\end{array}$ & $\begin{array}{l}0.85874 \\
2059\end{array}$ & $\begin{array}{l}\text { Strong } \\
\text { Structure }\end{array}$ \\
\hline 3 & Usaha 3 & $\begin{array}{c}1,2487 \\
1679\end{array}$ & $\begin{array}{c}9,9675 \\
208\end{array}$ & $\begin{array}{l}0.87447 \\
8073\end{array}$ & $\begin{array}{l}\text { Strong } \\
\text { Structure }\end{array}$ \\
\hline 4 & Usaha 4 & $\begin{array}{c}1,3657 \\
104 \\
\end{array}$ & $\begin{array}{c}9,7145 \\
029 \\
\end{array}$ & $\begin{array}{l}0.85874 \\
2059\end{array}$ & $\begin{array}{l}\text { Strong } \\
\text { Structure }\end{array}$ \\
\hline 5 & Usaha 5 & $\begin{array}{c}1,0682 \\
6938\end{array}$ & $\begin{array}{c}9,6610 \\
944 \\
\end{array}$ & $\begin{array}{l}0.88865 \\
2975\end{array}$ & $\begin{array}{l}\text { Strong } \\
\text { Structure }\end{array}$ \\
\hline 6 & Usaha 6 & $\begin{array}{c}7,9781 \\
3137\end{array}$ & $\begin{array}{c}9,0106 \\
376\end{array}$ & $\begin{array}{l}0.27010 \\
3541\end{array}$ & $\begin{array}{l}\text { Weak } \\
\text { Structure }\end{array}$ \\
\hline 7 & Usaha 7 & $\begin{array}{c}1,0962 \\
6272 \\
\end{array}$ & $\begin{array}{c}9,7338 \\
501 \\
\end{array}$ & $\begin{array}{l}0.88737 \\
6248\end{array}$ & $\begin{array}{l}\text { Strong } \\
\text { Structure }\end{array}$ \\
\hline 8 & Usaha 8 & $\begin{array}{c}1,1081 \\
027\end{array}$ & $\begin{array}{c}9,6753 \\
326 \\
\end{array}$ & $\begin{array}{l}0.88547 \\
1358\end{array}$ & $\begin{array}{l}\text { Strong } \\
\text { Structure }\end{array}$ \\
\hline 9 & Usaha 9 & $\begin{array}{c}1,3118 \\
1194\end{array}$ & $\begin{array}{c}10,187 \\
252\end{array}$ & $\begin{array}{l}0.87123 \\
0043\end{array}$ & $\begin{array}{l}\text { Strong } \\
\text { Structure }\end{array}$ \\
\hline 10 & Usaha 10 & $\begin{array}{c}3,6793 \\
2199\end{array}$ & $\begin{array}{c}9,0613 \\
446\end{array}$ & $\begin{array}{l}0.59395 \\
4082\end{array}$ & $\begin{array}{l}\text { Medium } \\
\text { Structure }\end{array}$ \\
\hline 11 & Usaha 11 & $\begin{array}{c}2,2318 \\
4155\end{array}$ & $\begin{array}{c}9,3121 \\
778 \\
\end{array}$ & $\begin{array}{l}0.76033 \\
087\end{array}$ & $\begin{array}{l}\text { Strong } \\
\text { Structure }\end{array}$ \\
\hline 12 & Usaha 12 & $\begin{array}{c}1,0608 \\
5465\end{array}$ & $\begin{array}{c}9,6526 \\
978\end{array}$ & $\begin{array}{l}0.89009 \\
76\end{array}$ & $\begin{array}{l}\text { Strong } \\
\text { Structure }\end{array}$ \\
\hline 13 & Usaha 13 & $\begin{array}{c}1,2682 \\
8987\end{array}$ & $\begin{array}{c}10,061 \\
682 \\
\end{array}$ & $\begin{array}{l}0.87394 \\
8518\end{array}$ & $\begin{array}{l}\text { Strong } \\
\text { Structure }\end{array}$ \\
\hline 14 & Usaha 14 & $\begin{array}{c}1,2703 \\
5454\end{array}$ & $\begin{array}{c}10,097 \\
409\end{array}$ & $\begin{array}{l}0.87419 \\
0044\end{array}$ & $\begin{array}{l}\text { Strong } \\
\text { Structure }\end{array}$ \\
\hline 15 & Usaha 15 & $\begin{array}{c}1,2416 \\
487\end{array}$ & $\begin{array}{c}9,9711 \\
553\end{array}$ & $\begin{array}{l}0.87547 \\
5945\end{array}$ & $\begin{array}{l}\text { Strong } \\
\text { Structure }\end{array}$ \\
\hline 16 & Usaha 16 & $\begin{array}{c}1,2836 \\
2137\end{array}$ & $\begin{array}{c}10,140 \\
371\end{array}$ & $\begin{array}{l}0.87341 \\
4756\end{array}$ & $\begin{array}{l}\text { Strong } \\
\text { Structure }\end{array}$ \\
\hline 17 & Usaha 17 & $\begin{array}{c}1,2540 \\
6491\end{array}$ & $\begin{array}{c}10,069 \\
329 \\
\end{array}$ & $\begin{array}{l}0.87545 \\
695\end{array}$ & $\begin{array}{l}\text { Strong } \\
\text { Structure }\end{array}$ \\
\hline 18 & Usaha 18 & $\begin{array}{c}8,7617 \\
3611\end{array}$ & $\begin{array}{c}9,5771 \\
165\end{array}$ & $\begin{array}{l}0.26508 \\
4042\end{array}$ & $\begin{array}{l}\text { Weak } \\
\text { Structure }\end{array}$ \\
\hline 19 & Usaha 19 & $\begin{array}{c}1,1062 \\
3229\end{array}$ & $\begin{array}{c}9,2332 \\
797\end{array}$ & $\begin{array}{l}0.88019 \\
0752\end{array}$ & $\begin{array}{l}\text { Strong } \\
\text { Structure }\end{array}$ \\
\hline 20 & Usaha 20 & $\begin{array}{c}1,1062 \\
3229\end{array}$ & $\begin{array}{c}9,2332 \\
797 \\
\end{array}$ & $\begin{array}{l}0.88019 \\
0752\end{array}$ & $\begin{array}{l}\text { Strong } \\
\text { Structure }\end{array}$ \\
\hline 21 & Usaha 21 & $\begin{array}{c}1,1181 \\
0932\end{array}$ & $\begin{array}{c}9,7750 \\
992\end{array}$ & $\begin{array}{l}0.88561 \\
6576\end{array}$ & $\begin{array}{l}\text { Strong } \\
\text { Structure }\end{array}$ \\
\hline 22 & Usaha 22 & $\begin{array}{c}1,0810 \\
1821\end{array}$ & $\begin{array}{c}9,6740 \\
857\end{array}$ & $\begin{array}{l}0.88825 \\
6292\end{array}$ & $\begin{array}{l}\text { Strong } \\
\text { Structure }\end{array}$ \\
\hline 23 & Usaha 23 & $\begin{array}{c}1,3428 \\
6279 \\
\end{array}$ & $\begin{array}{c}10,249 \\
382 \\
\end{array}$ & $\begin{array}{l}0.86898 \\
1097\end{array}$ & $\begin{array}{l}\text { Strong } \\
\text { Structure }\end{array}$ \\
\hline 24 & Usaha 24 & $\begin{array}{c}1,0902 \\
326\end{array}$ & $\begin{array}{c}9,7259 \\
363\end{array}$ & $\begin{array}{l}0.88790 \\
4612\end{array}$ & $\begin{array}{l}\text { Strong } \\
\text { Structure }\end{array}$ \\
\hline 25 & Usaha 25 & $\begin{array}{c}1,3504 \\
0397\end{array}$ & $\begin{array}{c}9,8716 \\
577\end{array}$ & $\begin{array}{l}0.86320 \\
393\end{array}$ & $\begin{array}{l}\text { Strong } \\
\text { Structure }\end{array}$ \\
\hline 26 & Usaha 26 & $\begin{array}{c}1,2886 \\
8812 \\
\end{array}$ & $\begin{array}{c}10,025 \\
513 \\
\end{array}$ & $\begin{array}{l}0.87145 \\
914\end{array}$ & $\begin{array}{l}\text { Strong } \\
\text { Structure }\end{array}$ \\
\hline 27 & Usaha 27 & $\begin{array}{c}1,4588 \\
532\end{array}$ & $\begin{array}{c}9,7402 \\
442\end{array}$ & $\begin{array}{l}0.85022 \\
4165\end{array}$ & $\begin{array}{l}\text { Strong } \\
\text { Structure }\end{array}$ \\
\hline 28 & Usaha 28 & $\begin{array}{c}1,1788 \\
6732\end{array}$ & $\begin{array}{c}9,3532 \\
241\end{array}$ & $\begin{array}{l}0.87396 \\
1394\end{array}$ & $\begin{array}{l}\text { Strong } \\
\text { Structure }\end{array}$ \\
\hline 29 & Usaha 29 & $\begin{array}{c}1,2001 \\
4811\end{array}$ & $\begin{array}{c}9,0864 \\
758\end{array}$ & $\begin{array}{l}0.86791 \\
9297\end{array}$ & $\begin{array}{l}\text { Strong } \\
\text { Structure }\end{array}$ \\
\hline 30 & Usaha 30 & $\begin{array}{c}1,3664 \\
0666\end{array}$ & $\begin{array}{c}9,6429 \\
983 \\
\end{array}$ & $\begin{array}{l}0.85830 \\
0642\end{array}$ & $\begin{array}{l}\text { Strong } \\
\text { Structure }\end{array}$ \\
\hline 31 & Usaha 31 & $\begin{array}{c}1,0701 \\
6204\end{array}$ & $\begin{array}{c}9,3185 \\
7\end{array}$ & $\begin{array}{l}0.88515 \\
8127\end{array}$ & $\begin{array}{l}\text { Strong } \\
\text { Structure }\end{array}$ \\
\hline
\end{tabular}




\begin{tabular}{|c|c|c|c|c|c|}
\hline No & Nama & a (i) & b (i) & $\mathrm{s}$ (i) & $\begin{array}{c}\text { Keteranga } \\
n\end{array}$ \\
\hline 32 & Usaha 32 & $\begin{array}{c}8,6529 \\
7401\end{array}$ & $\begin{array}{c}12,321 \\
033\end{array}$ & $\begin{array}{l}0.37052 \\
6075\end{array}$ & $\begin{array}{l}\text { Weak } \\
\text { Structure }\end{array}$ \\
\hline 33 & Usaha 33 & $\begin{array}{c}9,6781 \\
3778 \\
\end{array}$ & $\begin{array}{c}7,5839 \\
265 \\
\end{array}$ & $\begin{array}{l}0.03976 \\
4869 \\
\end{array}$ & $\begin{array}{l}\text { No } \\
\text { Structure }\end{array}$ \\
\hline 34 & Usaha 34 & $\begin{array}{c}2,9781 \\
641\end{array}$ & $\begin{array}{c}8,2964 \\
15\end{array}$ & $\begin{array}{l}0.64102 \\
9997\end{array}$ & $\begin{array}{l}\text { Medium } \\
\text { Structure }\end{array}$ \\
\hline 35 & Usaha 35 & $\begin{array}{c}1,3107 \\
3285\end{array}$ & $\begin{array}{c}9,5310 \\
821 \\
\end{array}$ & $\begin{array}{l}0.86247 \\
8065\end{array}$ & $\begin{array}{l}\text { Strong } \\
\text { Structure }\end{array}$ \\
\hline 36 & Usaha 36 & $\begin{array}{c}1,5275 \\
3535\end{array}$ & $\begin{array}{c}9,0203 \\
46\end{array}$ & $\begin{array}{l}0.83065 \\
668\end{array}$ & $\begin{array}{l}\text { Strong } \\
\text { Structure }\end{array}$ \\
\hline 37 & Usaha 37 & $\begin{array}{c}1,3062 \\
9087\end{array}$ & $\begin{array}{c}9,5516 \\
314 \\
\end{array}$ & $\begin{array}{l}0.86323 \\
8978 \\
\end{array}$ & $\begin{array}{l}\text { Strong } \\
\text { Structure }\end{array}$ \\
\hline 38 & Usaha 38 & $\begin{array}{c}1,0753 \\
0373 \\
\end{array}$ & $\begin{array}{c}9,5179 \\
169 \\
\end{array}$ & $\begin{array}{l}0.88702 \\
3207 \\
\end{array}$ & $\begin{array}{l}\text { Strong } \\
\text { Structure }\end{array}$ \\
\hline 39 & Usaha 39 & $\begin{array}{c}1,1547 \\
7866\end{array}$ & $\begin{array}{c}9,6923 \\
479 \\
\end{array}$ & $\begin{array}{l}0.88085 \\
6664\end{array}$ & $\begin{array}{l}\text { Strong } \\
\text { Structure }\end{array}$ \\
\hline 40 & Usaha 40 & $\begin{array}{c}1,0562 \\
1387 \\
\end{array}$ & $\begin{array}{c}9,5516 \\
314 \\
\end{array}$ & $\begin{array}{l}0.88942 \\
0579 \\
\end{array}$ & $\begin{array}{l}\text { Strong } \\
\text { Structure }\end{array}$ \\
\hline
\end{tabular}

Dari Tabel 6 dapat disimpulkan dengan perhitungan Shilhoute Coeficient menghasilkan nilai SC pada setiap cluster, terdapat 34 data Strong Structure artinya data UMKM yang masuk ke dalam cluster mikro terstruktur kuat, 2 data Medium Structure artinya data UMKM yang digunakan terstruktur baik, 3 data Weak Structure artinya data UMKM yang digunakan terstruktur lemah, 1 data No Structure artinya data UMKM yang digunakan terstruktur buruk.

\section{PENUTUP}

\subsection{Kesimpulan}

Berdasarkan hasil penelitian yang telah peneliti kerjakan dengan judul Pemetaan Persebaran UMKM di Kecamatan Karangmalang dengan Metode K-Means (Studi kasus: Dinas Koperasi dan UKM Sragen), maka dapat diambil kesimpulan bahwa dari 200 data yang dimasukan ke dalam program, diperoleh 176 data UMKM termasuk mikro, 22 data UMKM termasuk kecil, dan 2 data UMKM termasuk menengah sesuai dengan peraturan UU No 20 Tahun 2008 tentang UMKM. Dari 200 data UMKM diambil 40 data untuk diuji dengan metode Shilhoute Coeficient dengan $90 \%$ data UMKM yang terstruktur dengan baik. Hal ini menunjukan bahwa dengan menggunakan metode K-Means dapat mengelompokan tingkatan usaha maupun pemerataan bantuan UMKM mikro karena hasil perhitungan akan dipetakan ke dalam map Kecamatan Karangmalang sesuai cluster masing-masing.

\subsection{Saran}

1. Dengan adanya sistem klasterisasi UMKM di Kecamatan Karangmalang Kabupaten Sragen, dapat dikembangkan untuk kecamatan atau kabupaten daerah lain.
2. Sistem ini dapat dikembangkan dengan memberikan tambahan fitur print out data peta dan data hasil klasterisasi sebagai keluaran cetak data, sehingga sistem ini bisa menyediakan rekapitulasi data.

\section{DAFTAR PUSTAKA}

[1] G. Gustientiedina, M. H. Adiya, and Y. Desnelita, "Penerapan Algoritma KMeans Untuk Clustering Data ObatObatan," J. Nas. Teknol. dan Sist. Inf., vol. 5, no. 1, pp. 17-24, 2019.

[2] B. M. Metisen and H. L. Sari, "Analisis clustering menggunakan metode $\mathrm{K}$ Means dalam pengelompokkan penjualan produk pada Swalayan Fadhila," J. Media Infotama, vol. 11, no. 2, pp. 110-118, 2015.

[3] mohamad jajuli nurul rohmawati, sofi defiyanti, "Implementasi Algoritma KMeans Dalam Pengklasteran Mahasiswa Pelamar Beasiswa," Jitter 2015, vol. I, no. 2, pp. 62-68, 2015.

[4] W. Safira Azis and dan Dedy Atmajaya, "Pengelompokan Minat Baca Mahasiswa Menggunakan Metode K-Means," Ilk. J. IIm., vol. 8, no. 2, pp. 89-94, 2016.

[5] R. A. Asroni, "Penerapan Metode KMeans Untuk Clustering Mahasiswa Berdasarkan Nilai Akademik Dengan Weka Interface Studi Kasus Pada Jurusan Teknik Informatika UMM Magelang," IIm. Semesta Tek., vol. 18, no. 1, pp. 76-82, 2015.

[6] N. A. Widiastuti and N. A. Azizah Widiastuti, "Teknologi Geolocation Berbasis Android dengan Metode KMeans untuk Pemetaan UMKM di Kabupaten Jepara," J. Sist. Inf. Bisnis, vol. 8, no. 2, p. 218, 2018.

[7] P. Puntoriza and C. Fibriani, "Analisis Persebaran UMKM Kota Malang Menggunakan Cluster K-means," JOINS (Journal Inf. Syst., vol. 5, no. 1, pp. 8694, 2020.

[8] W. Aristika and W. J. Hartono, "Penerapan Clustering K-Means untuk Menentukan Pengaruh Media Sosial Facebook terhadap Usaha Mikro, Kecil dan Menengah (UMKM) di Kecamatan Pekanbaru Kota," J. IImu Komput. dan Bisnis, vol. 11, no. 1, pp. 2389-2395, 2020. 